\title{
Uji Efektifitas Bioetanol Menggunakan Eceng Gondok (Eichhornia crassipes) Sebagai Bahan Bakar Campuran Bensin Terhadap Unjuk Kerja Mesin Generator
}

\author{
Lucky Anzelina Wijaya, Nurhatika S, dan Sudarmanta B \\ Departemen Biologi, Fakultas Ilmu Alam, Institut Teknologi Sepuluh Nopember (ITS) \\ e-mail: anzelinalucky@gmail.com,nurhatika023@yahoo.com, sudarmanta@me.its.ac.id
}

\begin{abstract}
Abstrak-Pertumbuhan industri dan peningkatan jumlah penduduk berdampak pada peningkatan kebutuhan energi serta peningkatan pencemaran air. Eceng gondok merupakan salah satu gulma yang banyak dijumpai di perairan yang mengalami eutrofikasi. Eceng gondok (Eichhornia crassipes) memiliki kandungan selulosa $64,51 \%$ berat kering. Pretreatment dan hidrolisis $13 \mathrm{Kg}$ eceng gondok kering dapat menghasilkan kadar gula $18 \%$. Hasil dari kadar gula tersebut dapat difermentasi menggunakan mikroorganisme (Saccharomyces cerevisiae) sehingga mampu menghasilkan kadar etanol sebesar 5\% sebanyak $10 \mathrm{~L}$ dan menjadi $95 \%$ sebanyak $200 \mathrm{ml}$ setelah destilasi. Hasil uji properties viskositas pertalite $1.42 \mathrm{cSt}$ lebih tinggi dari bioethanol 0.38 cSt sehingga mempengaruhi daya. Hasil unjuk kerja mesin, Daya efektif , Torsi, dan Tekanan efektif rata-rata tertinggi menggunakan E50 bioetanol (50 \% bioetanol : $50 \%$ pertalite). Pemakaian bahan bakar spesifik dengan pembebanan 200 watt menunjukkan hasil tertinggi pada E0 pertalite (100\% pertalite).
\end{abstract}

Kata Kunci-Bioetanol, Eceng Gondok, Fermentasi, Saccharomices cereviseae.

\section{PENDAHULUAN}

$\mathrm{P}$ ERMASALAHAN yang terjadi di Indonesia saat ini yaitu pertumbuhan penduduk yang sangat cepat, dengan perkembangan bidang industri yang pesat menyebabkan peningkatan permintaan energi dan penurunan kualitas lingkungan [1]. Produksi bahan bakar minyak bumi (fosil) di Indonesia mengalami penurunan $10 \%$ setiap tahunnya [2], sedangkan tingkat konsumsi minyak rata-rata naik $6 \%$ per tahun [3].

Cadangan bahan bakar minyak Indonesia sangat terbatas, Indonesia hanya memiliki cadangan terbukti yaitu, minyak 3,7 miliar barel atau $0,3 \%$ dari cadangan terbukti dunia [4]. Untuk mengimbangi besarnya konsumsi bahan bakar minyak, Indonesia melakukan impor minyak untuk memenuhi kebutuhan energi bahan bakar minyak setiap harinya [5].

Upaya pemerintah untuk mengurangi konsumsi masyarakat terhadap BBM adalah dengan memanfaatkan energi alternative melalui Peraturan Presiden Republik Indonesia No. 5 Tahun 2006 tentang Kebijakan Energi Nasional. Pemerintah juga menargetkan pada tahun 2016 pemanfaatan BBN dapat mencapai angka 5\%. Salah satu contoh bahan bakar nabati adalah bioetanol. Saat ini banyak dilakukan penelitian dan pemanfaatan bioetanol sebagai bahan campuran (aditif) dari bensin yang sering disebut dengan gasohol E-n yang bernilai ekonomis, renewable dan ramah lingkungan [6].

Bioetanol merupakan salah satu bahan bakar alternatif yang mempunyai kelebihan dibandingkan bahan bakar minyak. Bioetanol menghasilkan emisi gas CO lebih rendah bila dibandingkan dengan bahan bakar minyak yaitu sekitar 19$25 \%$ [7]. Bioetanol diproduksi dari tanaman yang mengandung biomassa seperti gula, pati, lignoselulosa [8]. Produksi bioetanol dari selulosa umumnya melalui tahapan proses pretreatment, hidrolisis, fermentasi, dan destilasi. Proses pretreatment dilakukan untuk memudahkan pemecahan pati dan selulosa menjadi glukosa [9].

Beberapa penelitian mengenai produksi bioetanol dengan bahan baku eceng gondok telah dilakukan sebelumnya. Eceng gondok mengandung hemiselulosa 48,70 $\pm 0,027 \%$ dan selulosa $18,20 \pm 0,012 \%$ berat basah [10], $4,1 \%$ pati pada daun eceng gondok [11], mengandung selulosa $64 \%$ berat kering. Daun dan batang eceng gondok ini dapat dimanfaatkan sebagai bahan dasar bioetanol yang sangat potensial. Kadar glukosa dapat diperoleh dari proses pretreatment sebesar 8414,7287 $\mathrm{mg} / \mathrm{L}$ [12].

Salah satu sumber selulosa yang mudah ditemukan di semua perairan di Indonesia dengan ketersediaanya yang fluktuatif sepanjang tahun dan melimpah di alam adalah eceng gondok. Tumbuhan ini merupakan rumput air yang memiliki kecepatan tumbuh yang tinggi [13], sehingga dianggap sebagai gulma yang dapat merusak lingkungan perairan [11] Eceng gondok sering dianggap merugikan karena jumlahnya yang melimpah dibandingkan dengan pemanfaatannya yang minimum, meskipun demikian eceng gondok dapat juga digunakan sebagai material produksi kertas, wine, kerajinan tangan dan biogas [14].

Ketersedian eceng gondok yang melimpah di alam akan menimbulkan limbah dan pencemaran baru. Eceng gondok mengandung selulosa yang dapat diubah menjadi glukosa sebagai sumber karbon untuk produksi etanol $\left(\mathrm{C}_{2} \mathrm{H}_{5} \mathrm{OH}\right)$. Oleh karena itu dilakukan penelitian efektivitas penggunaan 
bioetanol dari daun dan batang eceng gondok (Eichhornia crassipes) sebagai bahan bakar campuran.

\section{TINJAUAN PUSTAKA}

\section{A. Eceng Gondok (Eichhornia crassipes)}

Eceng gondok ini merupakan salah satu bahan serat alam yang belum banyak dimanfaatkan, ketersediaannya di Indonesia sangat melimpah karena pertumbuhannya yang cepat. Berbagai upaya telah dilakukan untuk memberantas tanaman gulma perairan ini, namun tidak pernah berhasil karena tingkat pertumbuhan tanaman ini lebih cepat dari pembuangannya. Kandungan kimia eceng gondok terdiri atas $60 \%$ selulosa, $8 \%$ hemiselulosa dan $17 \%$ lignin [15], juga senyawa alkaloid, antrakuinon, flavonoid, flobatanin, glikosida jantung, saponin, steroid, terpenoid, kuinon, tanin dan polifenol [16] dan [17].

\section{B. Bioetanol}

Bioetanol adalah etanol yang dihasilkan dari proses fermentasi gula dari bahan nabati [18]. Etanol disebut juga etil etanol dengan rumus kimia $\mathrm{C}_{2} \mathrm{H}_{5} \mathrm{OH}$ atau $\mathrm{CH}_{3} \mathrm{CH}_{2} \mathrm{OH}$. Titik didih etanol adalah $78,4^{\circ} \mathrm{C}$. Etanol memiliki sifat tidak berwarna, volatil, dan dapat bercampur dengan air [19][20]. Etanol dapat dihasilkan melalui proses fermentasi dengan bantuan mikroorganisme Saccharomices cerevisiae [20]. Produksi bioetanol dari selulosa umumnya melalui tahapan proses pretreatment, hidrolisis, fermentasi, dan destilasi. Proses pretreatment dilakukan untuk memudahkan pemecahan pati dan selulosa menjadi glukosa [6]. Pretreatment dapat meningkatkan hasil gula yang diperoleh. Proses pretreatment dapat dilakukan dengan menggunakan zat kimia asam seperti $\mathrm{H}_{2} \mathrm{SO}_{4}, \mathrm{HCL}$, kapur, $\mathrm{Ca}(\mathrm{OH})_{2}$, ammonia fiber expansion (AFEX), ammonia recycle percolation (ARP), katalis, organosol, sulfite pretreatment top overcome recalcitrance (SPORL), ozone, oksidasi dengan alkali, jamur pelapuk putih [22].

\section{Uji Properties Bioetanol}

Properti bahan bakar adalah sifat atau karakter yang dimiliki oleh suatu bahan bakar yang terkait dengan kinerja bahan bakar tersebut dalam proses atomisasi dan pembakaran. Properti umum yang perlu diketahui untuk menilai kinerja bahan bakar motor bensin antara lain, Densitas didefinisikan sebagai perbandingan massa bahan bakar terhadap volum bahan bakar pada suhu acuan $15^{\circ}$ C. Sedangkan Spesific Gravity $(S G)$ didefinisikan sebagai perbandingan berat dari sejumlah volum minyak bakar terhadap berat air untuk volume yang sama pada suhu tertentu densitas bahan bakar, relatif terhadap air.

$$
S G_{\text {terhadap air }}=\frac{\text { densitas bahan bakar }_{\text {densitas air }}}{\text { and }}
$$

Viskositas adalah tahanan yang dimiliki fluida yang dialirkan dalam pipa kapiler terhadap gaya gravitasi, biasanya dinyatakan dalam waktu yang diperlukan untuk mengalir dalam jarak tertentu.

$$
v=C . t
$$

Flash point atau titik nyala suatu bahan bakar adalah suhu terendah dimana bahan bakar dapat dipanaskan sehingga uap mengeluarkan nyala sebentar bila dilewatkan suatu nyala api [23] dan [21].

\section{Unjuk Kerja Mesin}

Karakteristik operasi dan unjuk kerja dari mesin Generator Set biasanya berhubungan dengan :

Daya engine merupakan daya yang diberikan untuk mengatasi beban yang diberikan. Untuk pengukuran digunakan peralatan yang dinamakan dynamometer sehingga didapatkan torsi [22]. Daya yang dihasilkan pada mesin dapat dihitung berdasarkan beban pada generator listrik dan dinyatakan sebagai Daya Efektif pada Generator (Ne) [21]. Hubungan tersebut dinyatakan dengan rumus :

$$
N e=\frac{V \cdot i \cdot \cos \emptyset}{746 x \eta_{g e n,} x \eta_{b}} \quad(H p)
$$

Torsi adalah hasil pekalian gaya tangensial dengan lengannya sehingga memiliki satuan $\mathrm{Nm}$ (SI) atau ft.lb (British). Dalam satu revolusi dari poros engine, titik tertentu yang berada pada diameter terluar rotor (jari-jari, r) akan

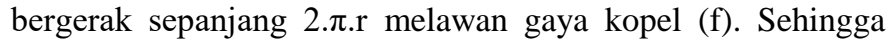
kerja per-revolusi adalah:

$$
\operatorname{Kerja}(W)=2 \times \pi \times r
$$

Tekanan Efektif Rata-rata (bmep) merupakan Proses pembakaran campuran udara-bahan bakar menghasilkan tekanan yang bekerja pada piston sehingga melakukan langkah kerja [24]. Tekanan efektif rata-rata dapat didefinisikan sebagai tekanan tetap rata-rata teoritis yang bekerja sepanjang volume langkah piston sehingga menghasilkan daya yang besarnya sama dengan daya efektif. Perumusan bmep adalah :

$$
\text { bmep }=\frac{60 \cdot \text { Ne } \cdot z}{A \cdot 1 \cdot n \cdot 1_{1} 34} \quad(\mathrm{kPa})
$$

Pemakaian bahan bakar spesifik (specific fuel consumption, $s f c$ ) adalah jumlah bahan bakar yang dipakai engine untuk menghasilkan daya efektif 1 (satu) Hp selama 1 (satu) jam [23]. Apabila dalam pengujian diperoleh data mengenai penggunaan bahan bakar $\mathrm{m}(\mathrm{kg})$ dalam waktu $\mathrm{s}$ (detik) dan daya yang dihasilkan sebesar bhp (Hp) maka pemakaian bahan bakar perjam adalah:

$$
\dot{\mathrm{m}}_{\mathrm{bb}}=\frac{3600 \cdot m_{b b}}{s} \quad\left(\frac{\mathrm{kg}}{j a m}\right)
$$

Sedangkan besarnya pemakaian bahan bakar spesifik adalah:

$$
s f c=\frac{3600 \cdot m_{b b}}{N e \cdot s} \quad(\mathrm{~kg} / \mathrm{Hp} . \mathrm{jam})
$$




\section{METODOLOGI}

\section{A. Pretreatment}

Daun dan batang eceng gondok sebanyak $13 \mathrm{~kg}$ berat kering diambil dari waduk kedurus, Surabaya. Pretreatment dilakukan secara fisik, daun dan batang eceng gondok dipisahkan dari akarnya, dicuci bersih, ditiriskan, dan dipotong kecil berukuran $3 \mathrm{~cm}$, kemudian dijemur dibawah terik matahari selama 14 hari.

\section{B. Proses Hidrolisis}

Bahan hasil pretreatment dihidrolisis, ditambahkan $25 \mathrm{~L}$ air, dipanaskan hingga mendidih sampai bahan menjadi layu. Bahan yang sudah didinginkan, diberi HCL $7 \%$ sebanyak $1 \mathrm{~L}$, diaduk sampai homogen, dan didiamkan selama 4 jam sampai pH $1-2$, kemudian dipanaskan pada suhu $100{ }^{\circ} \mathrm{C}$ hingga mendidih, kemudian didinginkan dan ditambahkan $\mathrm{NaOH} 10 \%$ sampai $\mathrm{pH} 4-4,5$ untuk menetralkan $\mathrm{pH}$.

\section{Proses Fermentasi}

Bahan hasil hidrolisis ditambahkan urea, NPK dan Saccharomyces cereviseae, 1,3\% dari volume total larutan, diaduk hingga homogen. Fermentasi dilakukan secara anaerob. Fermentor ditutup rapat dengan tutup galon dan plastisin untuk mencegah kontaminasi. Fermentor mengunakan galon dengan volume $18 \mathrm{~L}$, pada bagian tutup galon dilubangi untuk memberikan selang yang dimasukkan pada fermentor dan ujung selang dihubungkan dengan botol berisi air sebagai indicator fermentasi tersebut berhasil atau tidak. Fermentasi dilakukan selama 9 hari. Fermentasi tersebut berhasil dengan ditandai munculnya banyak gelembung gas pada botol indikator.

\section{Proses Destilasi}

Etanol dengan kadar tinggi, diperlukan destilasi dengan memasukkan kaldu fermentasi ke dalam destilator dengan suhu $80{ }^{\circ} \mathrm{C}$ untuk diuapkan. Hasil uap dari kondensor akan keluar melalui lubang kondensor yang dihubungkan dengan selang, Hasil destilasi yang didapatkan yaitu etanol dengan komposisi 95\%.

\section{E. Pengujian Kadar Etanol}

Untuk mengetahui kadar etanol dari hasil destilasi, dilakukan dengan cara mengambil sempel etanol hasil destilasi sebanyak $100 \mathrm{ml}$, dituangkan pada gelas ukur dan dimasukkan alkoholmeter untuk mengetahui kadar alkohol yang diperoleh.

\section{F. Analisis Kadar Gula}

Pengukuran kadar gula ditentukan dengan mengoleskan 2-3 tetes sampel larutan hasil sebelum fermentasi dan setelah proses fermentasi ke dalam alat refractometer.

\section{G. Pengujian Properties}

Setelah didapatkan dan diukur kadar etanol $95 \%$, dilakukan uji properties bioetanol untuk menilai sifat atau karakter bahan bakar yang terkait dengan kinerja bahan bakar mesin generator, antara lain : Densitas, Specific Gravity, Vikositas dan Flash Point

\section{H. Uji Unjuk Kerja Mesin}

Uji bioetanol pada unjuk kerja mesin generator dengan perbedaan konsentrasi bahan bakar 100\% Pertalite, 50\% Pertalite $+50 \%$ bioetanol, $100 \%$ bioetanol. Hasil unjuk kerja yang diperoleh diantaranya Daya Efektif (Bhp), Torsi, Tekanan Efektif Rata-Rata (Bmep) dan Konsumsi Bahan Bakar Spesifik (BSFC).

\section{HASIL DAN PEMBAHASAN}

Bahan baku lignoselulosa pada eceng gondok dapat dilakukan pretreatment menjadi glukosa. Selulosa terdiri atas monomer glukosa yang dihubungkan dengan ikatan $\beta-1,4-$ glikosida, dengan menghidrolisis ikatan glikosida dapat diperoleh glukosa, yang dimanfaatkan sebagai sumber karbon untuk produksi etanol $\left(\mathrm{C}_{2} \mathrm{H}_{5} \mathrm{OH}\right)$ [24]. Bioetanol dari bahan baku yang mengandung selulosa memerlukan proses pretreatment dan hidrolisis untuk menghasilkan glukosa $\left(\mathrm{C}_{6} \mathrm{H}_{12} \mathrm{O}_{6}\right)$ yang selanjutnya akan difermentasi untuk memperoleh bioetanol seperti pada tabel 1 .

Tabel 1

Tabel hasil proses eceng gondok menjadi bioetanol

\begin{tabular}{l|lcc}
\hline \hline No. & Perlakuan & Raw Material & Hasil \\
\hline 1. & Pretreatment & $39 \mathrm{Kg}$ & $13 \mathrm{Kg}$ \\
2. & Hidrolisis & $\mathrm{pH} \mathrm{1}$ & $\mathrm{pH} 4$ \\
\hline 3. & Fermentasi & $18 \mathrm{~L} \mathrm{substrat}$ & $5 \%$ bioetanol 10 L \\
4. & Gula Reduksi & $18 \%$ & $5 \%$ \\
\hline 5. & Destilasi & $5 \%$ & $95 \%$ \\
& & bioetanol 10 L & bioetanol $200 \mathrm{ml}$ \\
\hline \hline
\end{tabular}

Proses hidrolisis asam menggunakan HCL 7\% yang direndam selama 4 jam hingga $\mathrm{Ph}$ 1-2 dan dipanaskan pada suhu $100^{\circ} \mathrm{C}$ hingga mendidih. Proses ini berfungsi meningkatkan kereaktifan air dan sebagai katalis untuk mempercepat reaksi memecah komponen lignoselulosa menjadi monomer gula dengan hidrolisis menggunakan asam klorida (HCL) [25].

Pada proses fermentasi ini digunakan khamir Saccharomyces cereviseae yang berupa ragi roti komersial (fermipan). Penggunaan ragi ini bertujuan sebagai agen fermentasi untuk mengubah glukosa yang berasal dari proses hidrolisis menjadi etanol, sesuai penelitian [26], yang menyatakan bahwa Saccharomyces cereviseae merupakan mikroorganisme yang baik dalam merubah glukosa menjadi etanol. Kadar alkohol yang dihasilkan sebesar $5 \%$ dari proses fermentasi. Kadar alkohol yang dihasilkan ini lebih tinggi dari penelitian [27], dengan bahan baku yang sama yaitu 4,70\%. Pada proses uji unjuk kerja mesin diperlukan kadar etanol minimal yaitu $95 \%$, sehingga dari proses fermentasi yang menghasilkan kadar alkohol $5 \%$ diperlukan proses destilasi [28].

Pada fermentasi etanol Saccharomyces cereviceae mengubah glukosa menjadi etanol melalui jalur Embden 
Mayerhof Parnas Pathway (EMP). Satu molekul glukosa akan membentuk 2 molekul etanol dan $\mathrm{CO}_{2}$. Sehingga berdasarkan bobotnya secara teoritis 1 gram glkosa akan menghasilkan 0,51 gram etanol. Menurut [20], penelitiannya menunjukkan bahwa kombinasi antara waktu fermentasi yang lama dan jumlah ragi yang banyak akan menghasilkan etanol dengan kadar alkohol yang tinggi.

Pada proses perombakan gula menjadi etanol Saccharomyces cereviceae membutuhkan nutrisi untuk pertumbuhannya. Nutrisi ini dapat dipenuhi dengan penambahan NPK dan urea. Dalam fermentasi bioetanol, pupuk ditambahkan sebagai tambahan nutrisi bagi pertumbuhan mirkoorganisme fermentasi. $\left(\mathrm{NH}_{2}\right)_{2} \mathrm{CO}$ (Urea) dan $\mathrm{NH}_{4} \mathrm{H}_{2} \mathrm{PO}_{4}$ (NPK) berfungsi sebagai sumber nutrisi atau makronutrien pertumbuhan mikroba pada proses fermentasi [20].

Saccharomyces cerevisiae merupakan organisme fakultatif yang dapat menggunakan dengan baik sistem aerob maupun anaerob dengan memperoleh energi dari pemecahan glukosa. Saccharomyces cerevisiae menghasilkan alcohol dalam jumlah besar. Pada kondisi anaerob proses fermentasi berjalan lebih cepat sedangkan proses pertumbuhan berjalan lambat. Apabila terdapat aerasi, kecepatan fermentasi menurun dan sebaliknya proses respirasi lebih aktif [29]. Jika tujuan penggunaan Saccharomyces cerevisiae adalah untuk menghasilkan alkohol maka dibutuhkan kondisi anaerob, tetapi untuk pembuatan starter (biakan awal) diperlukan kondisi aerob [30]. Saccharomyces cerevisiae juga menghasilkan enzim glukoamilase, agar dihasilkan gula reduksi yang lebih banyak. Keberhasilan fermentasi akan tampak adanya gelembung udara pada selang fermentor. Adanya gelembung udara ini mengindikasikan adanya produk sampingan yaitu $\mathrm{CO}_{2}$ ini mengindikasikan bahwa mikroorganisme dalam fermentasi menggunakan NPK dan urea sebagai nutrisi untuk pertumbuhan dan melakukan metabolisme [30].

Kadar etanol yang dihasilkan setelah fermentasi masih rendah untuk digunakan dalam uji unjuk kerja mesin, sehingga untuk meningkatkan kadar etanol perlu dilakukan proses destilasi. Hal ini sesuai dengan pernyataan [28], bahwa untuk meningkatkan kemurnian bioetanol dari fermentasi, maka harus melalui proses destilasi.

Kadar gula reduksi sebelum fermentasi menunjukkan hasil $18 \%$ yang tergolong cukup bagus untuk digunakan sebagai kaldu fermentasi. Sedangkan hasil akhir setelah fermentasi menunjukkan penurunan hasil menjadi 5\%. Penurunan kadar gula reduksi dapat disebabkan karena kandungan gula digunakan oleh khamir komersial (S. cerevisiae) sebagai sumber karbon [6], Kandungan gula tersebut kemudian akan dikonversi menjadi bioetanol oleh khamir komersial ( $S$. cerevisiae).

Dalam menganalisis properties bahan bakar digunakan standarisasi. Standarisasi yang digunakan dikeluarkan oleh Badan Standarisasi Nasional, Kementrian Energi dan Sumber Daya Mineral Republik Indonesia, Direktorat Jendral Energi, Baru Terbarukan dan Konservasi Energi, nomor 7390: tahun
2012, PT 27-04 Bioenergi ICS 27.190 tentang Bioetanol terdenaturasi untuk gasohol (BSN, 2012).

\section{1) Analisis Uji Properties}

\section{a. Analisis densitas, Specific Grafity, dan API Grafity}

Specific Grafity (SG) merupakan perbandingan antara densitas suatu bahan bakar terhadap densitas air. Besarnya nilai SG bahan bakar akan sebanding dengan besarnya nilai densitas dan berbanding terbalik terhadap nilai API gravity [21]. Berdasarkan pengukuran, nilai Specific Grafity bioetanol murni dari eceng gondok dengan pertalite, dapat dilihat pada gambar 1.
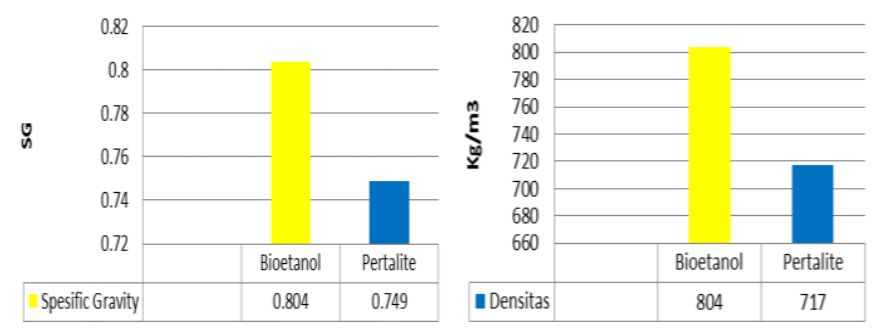

Gambar 1. Spesific Grafity bioetanol dan pertalite (SG) dan Grafik Densitas Bioetanol dan Pertalite $\left(\mathrm{Kg} / \mathrm{m}^{3}\right)$

Berdasarkan grafik diatas, nilai specific gravity bioetanol lebih besar dibandingkan pertalite. Hal ini dikarenakan dalam bioetanol masih terdapat gliserol dan fatty acid yang mempunyai nilai SG yang tinggi. Oleh karena itu, dengan masih terdapatnya kandungan gliserol dan fatty acid dalam minyak nabati murni maka specific grafity akan semakin tinggi pula [21].

Besarnya nilai SG mempengaruhi nilai densitas suatu bahan bakar. Dengan semakin besar SG maka semakin besar pula densitasnya. Densitas merupakan perbandingan massa suatu bahan bakar terhadap volume tertentu. Sehingga pada volume yang sama, bahan bakar dengan densitas tertinggi akan memiliki massa paling tinggi juga. Berdasarkan pengukuran, nilai densitas dapat dilihat pada gambar 1 .

Secara umum nilai densitas bioetanol lebih tinggi disbanding pertalite. Oleh karena itu pada volume yang sama massa bahan bakar bioetanol yang diinjeksikan ke dalam silinder akan lebih banyak daripada pertalite [21].

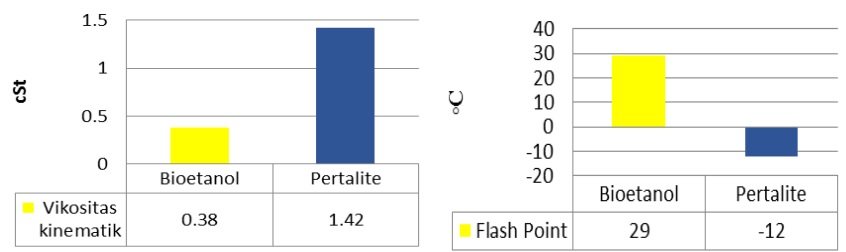

Gambar 2. Grafik Viskositas kinematik bioetanol dengan pertalite (cSt) dan Graafik Flash Point $\left({ }^{\circ} \mathrm{C}\right)$.

\section{b. Analisis Viskositas Kinematik}

Jika viskositas semakin tinggi, maka tahanan untuk mengalir akan semakin tinggi. Karakteristik ini sangat penting karena mempengaruhi kinerja injector pada mesin. Atomisasi 
bahan bakar sangat tergantung pada viskositas kinematik, tekanan injeksi, dan ukuran lubang injeksi. Viskositas lebih tinggi akan membuat bahan bakar teratomisasi menjadi tetesan yang lebih besar dengan momentum tinggi dan memiliki kecenderungan untuk pertumbukan dengan dinding silinder yang relatif lebih dingin. Viskositas kinematik yang relatif lebih tinggi mempunyai sifat pelumasan yang lebih baik [21].

\section{c. Analisis Flash Point}

Flash point adalah temperatur terendah dimana bahan bakar yang dipanaskan mampu menghasilkan campuran uap bahan bakar udara yang dapat menyala ketika ada sumber api yan didekatkan. Flash point pada bioetanol dari eceng gondok diperoleh hasil pada gambar 2 .

\section{2) Analisis Uji Unjuk Kerja Mesin}

a. Daya mengindikasikan besarnya kemampuan mesin untuk menghasilkan kerja persatuan waktu.

Daya efektif mesin atau brake horse power (bhp) adalah daya yang dikeluarkan olehporos mesin [23]. Daya mesin adalah jumlah energi yang dihasilkan mesin setiap waktunya [21]. Pada gambar 3 akan terlihat bahwa grafik kenaikan daya berbanding lurus dengan kenaikan beban.
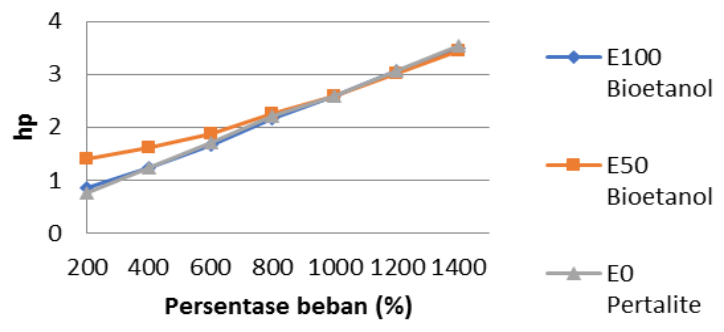

Gambar 3. Grafik daya efektif terhadap persentase beban.

Pada gambar 3 terlihat bahwa semakin tinggi beban yang diberikan, maka bahan bakar yang diinjeksikan ke ruang bakar semakin banyak. Daya efektif tertinggi dihassilkan dari E50 bioetanol (50\% bioetanol : $50 \%$ pertalite) yaitu dengan (hp 1.398169278) pada pembebanan 200 watt dan semakin tinggi pada pembebanan 1400 watt dengan (hp 3.441647454). Hal tersebut dilakukan untuk menjaga putaran mesin tetap konstan Sedangkan pada E100 bioetanol (100\% bioetanol) lebih rendah $19.64 \%$ dibandingkan E50 bioetanol dan E0 pertalite ( $100 \%$ pertalite) menunjukkan hasil terendah.

Hal tersebut dapat terjadi karena nilai kalor pertalite (46.5 $\mathrm{Mj} / \mathrm{Kg}$ ) dengan nilai kalor bioetanol (35.7 Mj/Kg) (Dimas dan Ansori, 2017), menjadi lebih tinggi dan nilai densitas bioetanol $\left(804 \mathrm{Kg} / \mathrm{m}^{3}\right)$ lebih tinggi daripada pertalite $\left(717 \mathrm{Kg} / \mathrm{m}^{3}\right)$. Daya yang dikeluarkan dari pengoperasian mesin akan ditentukan oleh beberapa faktor diantaranya kualitas bahan bakar, terutama komposisi yang mudah terbakar dan nilai kalor, kualitas campuran gas dan pembakaran, efisiensi mesin untuk mengubah bahan bakar campuran yang mudah terbakar menjadi energi mekanik [31].

\section{b. Analisis Torsi}

Torsi adalah ukuran kemampuan mesin untuk melakukan kerja, jadi torsi adalah suatu energi [31]. Makin tinggi beban yang diberikan, maka torsi yang dihasilkan juga akan naik. Hal ini disebabkan ketika beban ditambahkan maka bahan bakar yang diinjeksikan juga akan bertambah untuk menjaga putaran tetap konstan [21]. Pada gambar 4 akan terlihat kenaikan nilai torsi sebanding dengan beban yang diberikan.

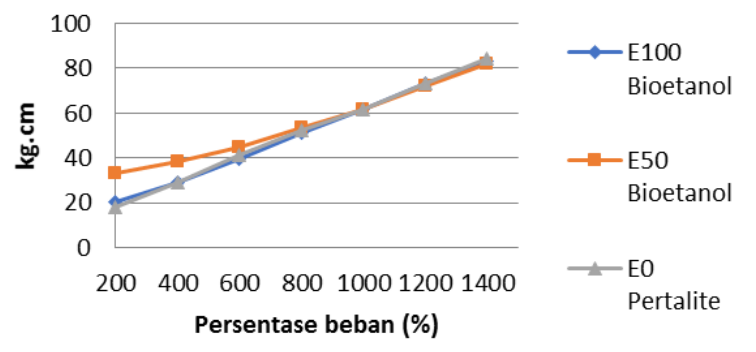

Gambar 4. Grafik torsi terhadap persentase beban

Gambar 4 menunjukkan nilai tertinggi dihasilkan dari E50 bioetanol (50\% bioetanol : $50 \%$ pertalite) yaitu dengan $(33.183 \mathrm{~kg} / \mathrm{cm})$ pada pembebanan 200 watt dan terus mengalami peningkatan sebanding dengan penambahan beban. Sedangkan nilai terendah ditunjukkan oleh E0 pertalite ( 100 $\%$ pertalite) dengan nilai $(17.905 \mathrm{~kg} / \mathrm{cm})$ pada pembebanan 200 watt.

Hal ini disebabkan oleh nilai kalor pertalite $(46.5 \mathrm{Mj} / \mathrm{Kg})$ lebih tinggi dari nilai kalor bioetanol (35.7 Mj/Kg) [32] dan viskositas pertalite yang lebih tinggi. Nilai viskositas yang semakin tinggi, maka tahanan untuk mengalir akan semakin tinggi dan energi yang dihasilkan semakin besar [21]. Besarnya torsi adalah besaran turunan yang biasa digunakan untuk menghitung energi yang dihasilkan dari benda yang berputar pada porosnya [31].

\section{c. Analisis Tekanan Efektif Rata-Rata (Bmep)}

Tekanan efektif rata-rata didefinisikan sebagai tekanan langkah piston sehingga menghasilkan daya yang besarnya sama dengan daya efektif. Dari gambar 5 terlihat bahwa Bmep naik seiring dengan penambahan beban.

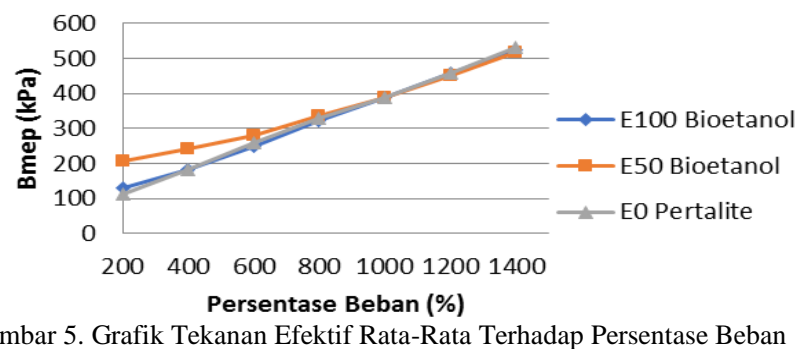

Dari gambar 5 terlihat bahwa Bmep naik seiring dengan penambahan beban. Nilai tekanan efektif rata-rata yang dihasilkan oleh mesin pada grafik 5 menunjukkan hasil tertinggi dari E50 bioetanol (50\% bioetanol : $50 \%$ pertalite) yaitu dengan ( $208.5052126 \mathrm{kPa}$ ) pada pembebanan 200 watt 
dan semakin tinggi pada pembebanan 1400 watt dengan $(516.0129003 \mathrm{kPa})$. Sedangkan pada E100 bioetanol (100\% bioetanol) lebih rendah $19.64 \%$ dibandingkan E50 bioetanol ( 505 bioetanol : $50 \%$ pertalite ) dan E0 pertalite ( $100 \%$ pertalite) menunjukkan hasil terendah. Hal tersebut dapat terjadi karena nilai kalor pertalite $(46.5 \mathrm{Mj} / \mathrm{Kg})$ lebih tinggi dibanding dengan nilai kalor bioetanol $(35.7 \mathrm{Mj} / \mathrm{Kg})$ [32].

Nilai kalor akan mempengaruhi tekanan efektif yang dihasilkan oleh mesin dan tekanan efektif akan meningkat sebanding dengan beban yang diberikan. Bertambahnya beban maka tekanan yang diberikan terhadap piston harus bertambah pula. Untuk menghasilkan tekanan yang lebih tinggi, maka energi yang dibutuhkan juga harus lebih besar. Besarnya Bmep dipengaruhi oleh besarnya nilai kalor, karena energi yang dilepaskan juga semakin besar. Tekanan langkah piston akan mengakibatkan daya meningkat. Parameter yang digunakan untuk menggambarkan kinerja mesin yaitu dengan tekanan efektif. Tekanan efektif (bmep) merupakan konstanta teoritis, jika itu terjadi pada piston saat bekerja dan akan menghasilkan tekanan yang sama dalam satu putaran [31].

\section{d. Analisis Konsumsi Bahan Bakar}

Pemakaian bahan bakar spesifik (Spesifik Fuel Consumption) didefinisikan sebagai jumlah bahan bakar yang dikonsumsi engine untuk menghasilkan daya efektif sebesar 1 hp selama 1 jam [31]. Pada gambar 6 dapat dilihat nilai dari konsumsi bahan bakar terhadap beban.

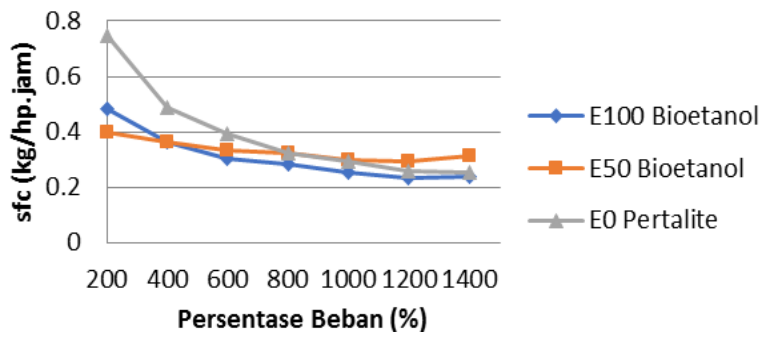

Gambar 6. Grafik konsumsi bahan bakar spesifik terhadap persentase beban

Pada gambar 6. pemakaian bahan bakar spesifik dengan pembebanan 200 watt menunjukkan hasil tertinggi pada E0 pertalite $(100 \%$ pertalite $)$ yaitu $(0.748952026 \mathrm{~kg} / \mathrm{hp} . \mathrm{jam})$ dan mengalami penurunan seiring dengan bertambahnya pembebanan sampai dengan pembebanan 1200 watt. Konsumsi bahan bakar akan mengalami kenaikkan mencapai $70 \%$ pada pembebanan tertentu yaitu pada grafik 4.6 ditunjukkan pada pembebanan 1400 watt. Sfc (Spesifik Fuel Consumption) merupakan representasi keefektifan mesin dalam mengkonsumsi bahan bakar. Makin rendah nilai sfc maka tingkat keefektifan bahan bakar makin tinggi atau dengan kata lain lebih irit [24]. Dari data grafik 4.6 menunjukan semakin bertambahnya beban, pemakaian bahan bakar spesifik cenderung turun.

\section{KESIMPULAN/RINGKASAN}

Berdasarkan penelitian yang telah dilakukan, dapat disimpulkan bahwa :

1. Daun dan batang eceng gondok segar sebanyak $39 \mathrm{Kg}$ yang dikeringkan menjadi $13 \mathrm{Kg}$ dan dihidrolisis dapat menghasilkan kadar gula $18 \%$.

2. Hasil dari fermentasi mampu menghasilkan kadar etanol sebesar $5 \%$ sebanyak $10 \mathrm{~L}$.

3. Kadar etanol dengan destilasi, mencapai hasil sebanyak $200 \mathrm{ml}$ dengan kadar $95 \%$.

4. Hasil uji properties viskositas pertalite $1.42 \mathrm{cSt}$ lebih tinggi dari bioethanol $0.38 \mathrm{cSt}$ sehingga mempengaruhi daya.

5. Daya efektif tertinggi dihassilkan dari E50 bioetanol (50\% bioetanol : $50 \%$ pertalite).

6. Torsi tertinggi dihasilkan dari E50 bioetanol (50\% bioetanol : $50 \%$ pertalite).

7. Tekanan efektif rata-rata tertinggi dari E50 bioetanol (50\% bioetanol : $50 \%$ pertalite).

8. Pemakaian bahan bakar spesifik dengan pembebanan 200 watt menunjukkan hasil tertinggi pada E0 pertalite (100\% pertalite).

\section{SARAN}

Berdasarkan penelitian yang telah dilakukan, maka dapat dilakukan pengajuan saran terhadap penelitian selanjutnya antara lain :

1.Perlu dilakukan penilitian dengan melakukan pemilihan bahan baku yang mengandung selulosa lebih besar sehingga mampu menghasilkan kadar gula lebih tinggi

2.Proses pretreatment menggunakan asam perlu dilakukan pengulangan dengan pretreatment menggunakan enzim untuk menghasilkan kadar gula yang lebih tinggi, sehingga hasil dari fermentasi memiliki kadar etanol tinggi.

3.Proses destilasi perlu dilakukan pengulangan untuk menghasilkan kadar etanol mencapai $99 \%$.

\section{DAFTAR PUSTAKA}

[1]

[2]
D. Widodo, "Rekayasa dan pengujian reaktor biogas skala kelompok tani ternak," J. Enjiring Pertan., pp. 41-52, 2006.

H. Lin, Y., Zhang, W., Li, C., Sakakibara, K., Tanaka, S., \& Kong, "Factors affecting ethanol fermentation using saccharomyces cerevisiae BY4742," J Biomass Bioenergy, vol. 47, pp. 395-401, 2012.

D. and S. G. H. Asteriou, "Applied Econometrics: A Modern Approach," in Data Produk Domestik Bruto, Inflasi dan Indeks Harga Konsumen (IHK) periode 2000 - 2011, New York, 2007.

K. E. dan S. D. Mineral, Permen ESDM No.14 Tahun 2012, tentang manajemen energi. Jakarta, 2012.

Rama, Menghasilkan Biodiesel Murah Mengatasi Polusi \& Kelangkaan BBM. Jakarta: PT ArgoMedia Pustaka, 2007.

Azizah, "Pengaruh lama fermentasi terhadap kadar alcohol, $\mathrm{pH}$, dan produksi gas pada proses fermentasi bioetanol dari whey dengan substitusi kulit nanas," Universitas Diponegoro, 2012.

D. . Syam, K.L., Farikha, J., dan Fitriana, "Pemanfaatan Limbah Pod Kakao Untuk Menghasilkan Bioetanol Sebagai Sumber Energi Terbarukan," Institut Pertanian Bogor, 2009.

K. B. Kim, T. H., Taylor, F., Hicks, "Bioethanol production from barley hull usingSAA (soaking in aqueous ammonia) pretreatment," Bioresour. Technol, vol. 99, pp. 5694-5702, 2008.

T. dan Karimi, "Review : Pretreatment of Lignocellulosic Wastes to Improve Ethanol and Biogas Production," Int. J. Mol. Sci, vol. 9, pp. 1621-1651, 2008.

and Y. Z. H. Lin, B. Wanga, R. Zhuang, Q.C. Zhou, "Artificial construction and characterization of a fungal consortium that produces cellulolytic enzyme system with strong wheat straw saccharification," Bioresour. Technol., vol. 102, pp. 10569-10576, 2011.

R. . Astuti, "Analisis Kandungan Nutrisi pada Eceng Gondok," Institute Peratanian Bogor, 2008.

F. dan Yulinah, "PRODUKSI BIOETANOL DARI ECENG GONdOK (Eichhornia crassipes) dengan Zymomonas mobilis dan 
Saccharomyces cerevisiae," ITS, 2011.

[13] P. . Deshpande, S.K., Bhotmange, M.G., Chakrabarti, T., dan Shastri, "Production of Cellulase and Xylanase by Trichoderma reesei (QM 9414 Mutant), Aspergillus niger and Mixed Culture by Solid State Fermentation (SSF) of Water Hyacinth (Eichhornia crassipes)," Indian J. Chem. Technol., vol. 15, pp. 449-456, 2008.

[14] N. Umsakul, K., Dissara, Y., dan Srimuang, "Chemical, Physical and Microbiological Changes during Composting of the Water Hyacinth," Pakistan J. Biol. Sci., vol. 13, no. 20, pp. 985-992, 2010.

[15] A. N. Ahmed, A.F., Moahmed A, Pretreatment and enzymic saccharification of water hyacinth cellulose. 2012.

[16] V. Lata, N., dan Dubey, "Preliminary Phytochemical Screening of Eichhornia crassipes: The World's Worst Aquatic Weed," $J$. Pharm. Res., vol. 3, no. 6, pp. 1240 - 1242, 2010.

[17] A. Widyaningrum, H. dan Rahmat, Kitab Tanaman Obat Nusantara. Yogyakarta: MedPress, 2011.

[18] T. Anindyawati, "Prospek Enzim dan Limbah Lignoselulosa untuk Produksi Bioetanol," Bogor, 2009.

[19] dan I. Kartika, B., Guritno, A. D., "Petunjuk Evaluasi Produk Industri Hasil Pertanian," Yogyakarta, 1997.

[20] S. H. Endah D.H., Erma P., "EFEKTIFITAS PENAMBAHAN RAGI DAN PUPUK TERHADAP KADAR ALKOHOL BIOETANOL DENGAN BAHAN BAKU JAMBU CITRA," Universitas Diponegoro, 2015.

[21] S. D. Setiyadi B., "Studi eksperimental pengaruh penguna minyak nabati murni (Straight Vegetable Oil) dari biji jarak, Wijen, Zaitun dan kelapa sawit terhadap unjuk kerja mesin disel putaran konstan," ITS, 2009.

[22] and K.-J. C. Lee, S.S., J.K.Ha, H.S.Kang, T. McAllister, "Overview of energy metabolism, substrate utilization and fermentation characteristics of ruminal anaerobic fungi," KoreanJ. Anim. Nutr. Feed., vol. 21, pp. 295-314, 1997.

[23] S. I. . Sudarmanta, B., Junipitoyo, B., Putra A.B.K., "INFLUENCE OF THE COMPRESSION RATIO AND IGNITION TIMING ON SINJAI ENGINE PERFORMANCE WITH 50\% BIOETHANOL
GASOLINE BLENDED FUEL," ARPN J. Eng. Appl. Sci., vol. 11, no. 4,2016

[24] S. Kamara, D.S., Rachman, S.D., dan Gaffar, "Degradasi Enzimatik Selulosa dari Batang Pohon Pisang untuk Produksi Enzim Selulase dari Kapang Trichoderma viride," Universitas Padjajaran, 2006.

[25] dan S. B. Erdei, B., Barta Z., "Etahnol Production From Mixtures Of Wheat Straw and Wheat Meal," Biotehnol, vol. 3, no. 16, 2010.

[26] A. M. and S. S. Rahayu, "Essential Oil from Extraction and Steam Distillation of Ocimum Basillicum," in Proceedings of the World Congress on Engineering and Computer Science 2007, 2007.

[27] C. Amaral, "PEMANFAATAN SAMPAH DAUN ECENG GONDOK (Eichhornia crassipes) MENJADI BIOETANOL DENGAN PROSES FERMENTASI SEBAGAI SOLUSI ENERGI ALTERNATIF," Universitas Diponegoro, 2012.

[28] S. Benjaphokee, S., Hasegawa, D., Yokota, D., Asvarak, T., Auesukaree, C., Sugiyama, M., Kaneko, Y., Boonchird, C., Harashima, "Highly efficient bioethanol production a Saccharomyces cerevisiae strain with multiple stress tolerance to high temperature, acid, and ethanol," N. Biotechnol, vol. 29, no. 3, pp. 379-86, 2012.

[29] N. . Chisilia, "Pemanfaatan Saccharomyces cerevisiae Dalam Sistem Microbial Fuel Cell Untuk Produksi Energi Listrik," Universitas Indonesia, 2011.

[30] M. K. Rini, "OPTIMALISASI FERMENTOR UNTUK PRODUKSI ETANOL DAN ANALISIS HASIL FERMENTASI MENGGUNAKAN GAS CHROMATOGRAFI," Universitas Gadjah Mada, 2014.

[31] S. B, "DUAL FUEL ENGINE PERFORMANCE USING BIODIESEL AND SYN-GAS FROM RICE HUSK DOWNDRAFT GASIFICATION FOR POWER GENERATION,” ITS, 2015.

[32] D. dan Ansori, "STUDI KOMPARASI PERFORMA MESIN BERBAHAN BAKAR PERTALITE DENGAN CAMPURAN PREMIUM DAN PERTAMAX PADA BERBAGAI VARIASI PADA SEPEDA MOTOR NEW HONDA VARIO 110 FI," UNESA, 2017. 